\title{
SHORT PERIOD CHANGE DETECTION OF SPERCHIOS LOWER DELTA AREA USING SPACE RADAR IMAGES
}

\author{
Em. Psomiadis and G. Migiros \\ Minerology-Geology laboratory, Agricultural University of Athens, lera Odos 75, 11855 , Athens \\ mpsomiadis@aua.gr, bagm@aua.gr
}

Is. Parcharidis

Space Applications Research Unit in Geosciences, Laboratory of Geophysics, National and Kapodistrian University of Athens, Panepistimiopolis-llissia, Athens 157 8, parchar@geol.uoa.gr

S. Poulos

National and Kapodistrian University of Athens, Faculty of Geology, Department of Physical

Geography \& Climatology, Panepistimiopolis-llissia, Athens 157 84, poulos@geol.uoa.gr

\section{ABSTRACT}

Being highly dynamic by nature, due to their changing hydrological regime and to the encroachment of urbanization, industrialization and changing patterns in agriculture, reliable and timely information of coastal areas is a prerequisite for their effective management.

The aim of this paper is to assess the use of ERS-2 SAR satellite data to detect short period changes in the case of the R. Sperchios coastal area that is located at the eastern part of the Maliakos Gulf (near the middle of the east coast of the Greek mainland). A Landsat 7 (ETM+) image served as a reference for the interpretation of the ERS images.

In order to highlight and detect the changes occurred in the study area two methods were applied. The first method is based on the creation of a Temporal Differentiate Image, consisted of the three ERS-2 images (Figure 1). The second method concerns the implementation of Principal Component Transform (PCT) on the three multitemporal scenes.

The final images derived from the two different methods were compared and evaluated. Both methods didn't show any significant change along the coastline. PCT method illustrates more clearly the seasonal changes of crops in the lower delta area. Eventually, radar technology gave the opportunity to discriminate shallow areas, which does not appear in satellite optical data. Concurrently, the effect of wind direction was investigated.

\section{INTRODUCTION}

Coastal zones are one of the most complicated earth-ecosystems with a large number of living and non-living recourses; therefore, coastal zones are areas of major socio-economical importance, worldwide (Constanza et al. 1997) Between the various morphological types of coastal zone, river deltas represent a highly dynamic land-water interface that is subjected also to a strong pressure of several natural (e.g. climatic change) and anthropogenic (e.g. urbanisation, transportation, tourism, cultivations) factors.

Remote sensing satellite data provide a unique tool for research and monitoring coastal areas and deltaic environments (Ciavola et al. 1999; Yang et al. 1999). Additionally, mapping of the coastline using multitemporal satellite data has been proved to be an important tool, as existing maps are often not accurate (in the first place) and not updated thus sometimes unable to follow rapid coastline changes (White \& El Asmar 1999; Shaghude et al. 2003).

The area under investigation is the deltaic plain and the mouth area of the River Sperchios that debouches to the eastern coast of the Maliakos Gulf; the latter is a semi-enclosed embayment located on the east coast of the Greek mainland (Fig. 1).

The purpose of this study is to assess the seasonal behaviour of Sperchios R. coastal deltaic plain for the time span of June 1998 to October 1999. The recognition of those changes was accomplished through the comparative study of ERS-2 radar data assisted by a Standard 
Geographical Information System (GIS) measurement tools. For this reason a multitemporal product from ERS.SAR images and a Principal Component Transform was created giving the opportunity of seasonal coastal changes (Rao et al. 1999, Kuntz \& Siegert 1999).

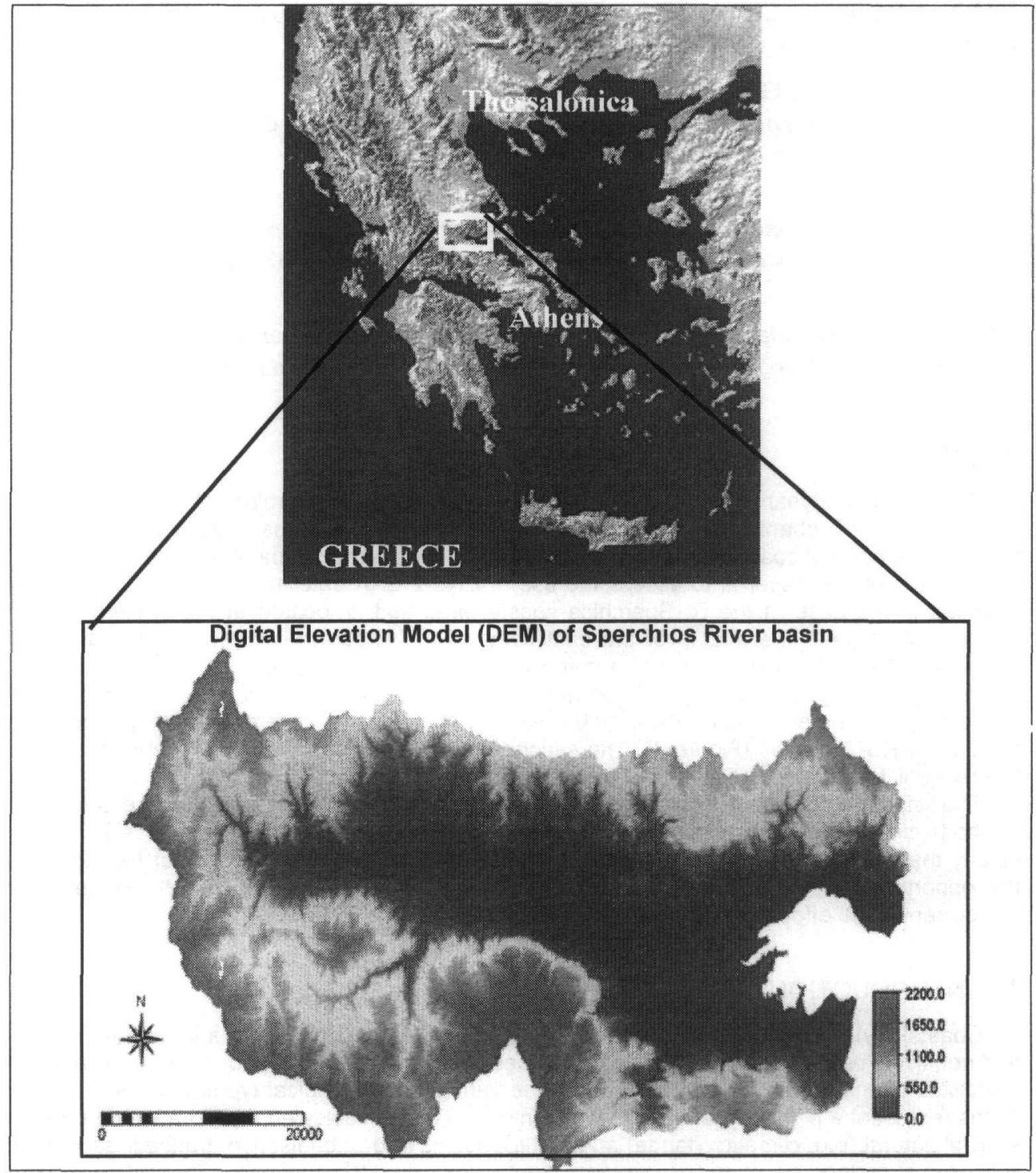

Figure 1. Location of the study area.

\section{THE STUDY AREA}

\subsection{Physical Geographical setting}

The River Sperchios runs through a valley, which is a graben-like asymmetrical depression with an E-W direction, parallel to the active fault of Atalanti. The graben that covers an area of some $1.780 \mathrm{~km}^{2}$ is approximately $60-80 \mathrm{~km}$ long, $20-30 \mathrm{~km}$ wide and having its southern and western flanks characterized by high elevations and steep slopes (Mt. Tymphristos $2.315 \mathrm{~m}$ and Mt. Iti 2.152 $\mathrm{m})$, whilst its northern flank presents lower elevations (Mt. Othrys $1.720 \mathrm{~m}$ ) and more gently slopes. 
The main channel of Sperchios River flows from west to east receiving the fluxes from more than twenty major tributaries, with most of them, joining the R. Sperchios almost at right angles. The R. Sperchios has a mean annual water discharge of $62 \mathrm{~m}^{3} / \mathrm{s}$, varying between $110 \mathrm{~m}^{3} / \mathrm{s}$ (in January) and $22 \mathrm{~m}^{3} / \mathrm{s}$ (in August) (Therianos, 1974). Flood events occur regularly exceeding the channel capacity. For example, on 29th June 1939 a flood discharge estimated at $800 \mathrm{~m}^{3} / \mathrm{s}$ occurred, in response primarily to sudden snowmelt (Zamani \& Maroukian, 1979). Furthermore, the total annual sediment load of the R. Sperchios has been estimated to be in excess of $1,5 \times 10^{6}$ tonnes/year (Poulos et al., 1997).

The R. Sperchios discharge at the west and southwest end of the Maliakos Gulf that is a semienclosed embayment with water depths less than $30 \mathrm{~m}$. The average length of the Gulf, in an eastwest direction, is about $11 \mathrm{~km}$, whilst its north-south width is approx. $9 \mathrm{~km}$. The strait that connects the Gulf with the north Euboic Gulf has a width of about $2,5 \mathrm{~km}$ and water depths of $25 \mathrm{~m}$. The sub aerial deltaic plain of R. Sperchios that between the $480 \mathrm{BC}$ and 1970 A.D. were extended by $\sim 100$ $\mathrm{km}^{2}$; this corresponds to a mean annual growth of $0,04 \mathrm{~km}^{2} / \mathrm{yr}$ (Zamani \& Maroukian, 1980).

\subsection{Geological setting}

Maliakos Gulf, together with the valley of the River Sperchios, forms part of a tectonic trough which is controlled by major NW-SE and E-W trending faults parallel to Atalanti normal fault zone. The fault tectonism took place at the end of the Pliocene and beginning of the Pleistocene periods. The Pliocene deposits, located to the south of the Maliakos Gulf, have been uplifted by more than $500 \mathrm{~m}$. Furthermore, the mountainous region at the southern boundary of the River Sperchios' catchment area was subjected to tectonic activity for a much longer period during the Quaternary; this has resulted in a vertical displacement of about $1.800 \mathrm{~m}$. The area experiences also strong earthquakes, like those which occurred in 426 B.C. and 1894 A.D. and induced big disastrous in the broader area (Pirazzoli et al. 1999).

In the drainage basin of River Sperchios, there are three distinct lithological regions (Fig.2) according to Ferrière (1977); these are:

(i) the western half is composed of Paleocene-Eocene flysch of the East Pindus and Parnassos (Iti) geotectonic zones; it is composed of alternating beds of argillite-siltstone-fine conglomerate and intercalations of shale. There is also a limited occurrence of pelagic and marly limestones of the Vardoussia zone in this area.

(ii) the south-eastern portion of the basin is composed of Middle Triassic-Jurassic massive dolomites and limestones of the Pelagonian zone; Upper Cretaceous flysch consisting of coarse sandstone alternating with shale and sandy marl belonging to the zone of Beotia; and Upper Cretaceous thickly-bedded limestones and Eocene flysch, composed of sandstone, clay and marl of the Parnassos geotectonic zone, and

(iii) in the north and north-eastern part, the lithological composition is completely different. Here, there is an ophiolithic complex in a shale-chert formation composed of shale, chert and limestone with ultra-basic and basic igneous rocks-peridotite, dunite, pyroxenite, gabbro, serpentine, diabase, dolerite and metamorphosed green phyllite and schist; these belong to Maliakos (Subpelagonian) zone.

In addition, Neogene and Quaternary unconsolidated deposits occupy the central and lower (elevations $<500 \mathrm{~m}$ ) part of the elongated drainage basin of the R. Sperchios (Maroukian \& Lagios 1987; Gartzos \& Stamatis 1996).

\subsection{Climatic and Oceanographic Setting}

The climate of Maliakos Gulf and its surrounding area is a typical Mediterranean with dry periods in summer and early autumn and precipitation in winter and spring. Average monthly air temperatures are from $8^{\circ}$ to $28^{\circ} \mathrm{C}$ (Lamia Meteorological station) and mean measured rainfall varies between $560 \mathrm{~mm} / \mathrm{yr}$ and $1750 \mathrm{~mm} / \mathrm{yr}$ depending upon the different altitudes; the later is associated with the amount of snow in higher altitudes (Stahl et al.1975). The predominant wind components are mostly from the east and west, following the localized east-west trend of the R. Sperchios valley. Average wind speeds are $1-2,5 \mathrm{~m} / \mathrm{s}$ for the westerly winds and $2,5-4,5 \mathrm{~m} / \mathrm{s}$ for those from the east (Poulos et al., 1997a). 
The Maliakos Gulf experiences low wave activity due to restricted fetches and related weak to moderate winds; this is associated with distinctly weak coastal erosional processes. The tidal range varies between $0.95 \mathrm{~m}$ (during spring tides) and $0.15 \mathrm{~m}$ (during neap tides) (Zamani \& Maroukian, 1980). The same authors have mentioned also the presence of a weak coastal current flowing from east to west, along the northern part of the gulf.

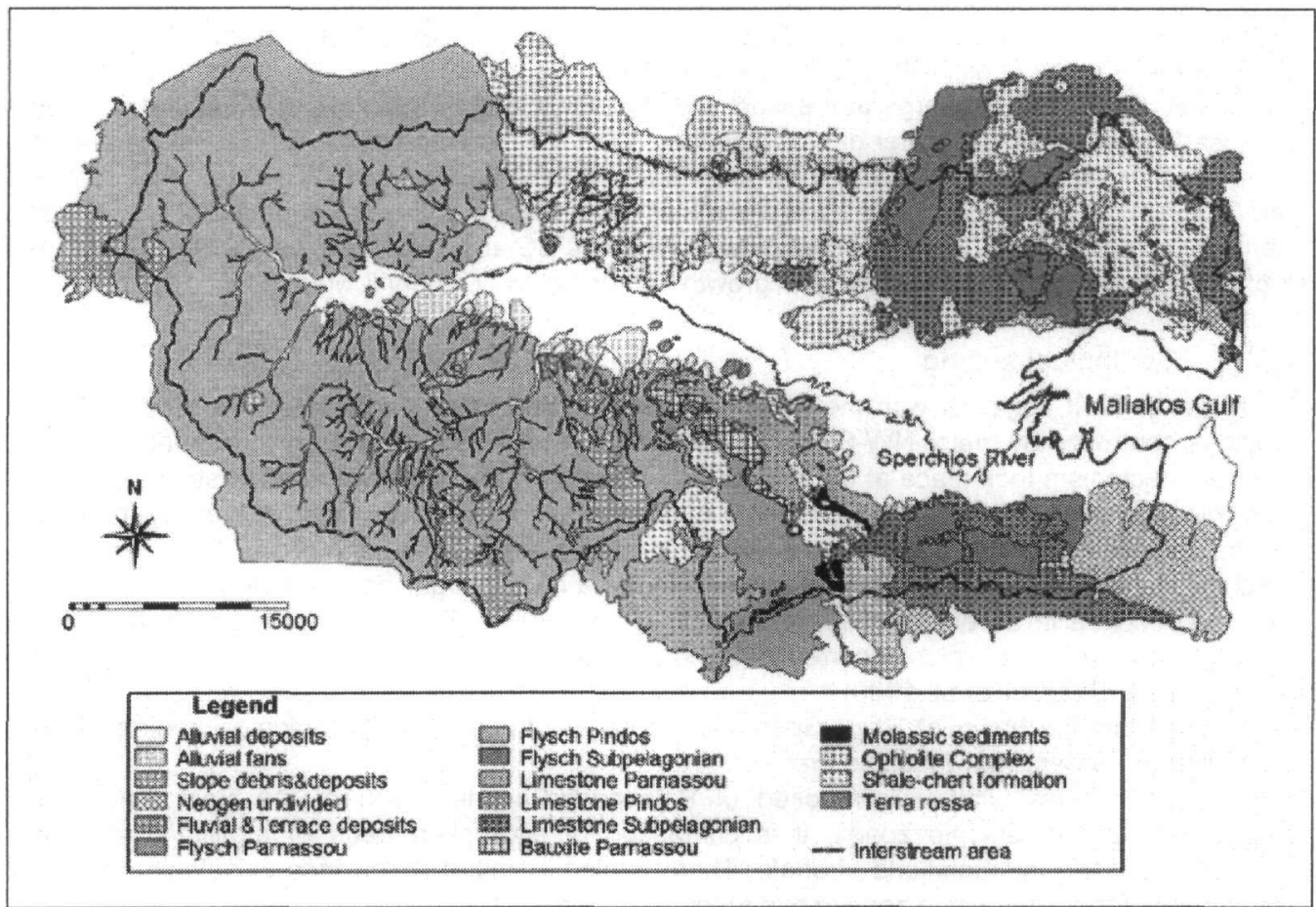

Figure 2. Simplified lithological map of Sperchios River basin.

\section{DATA COLLECTION AND METHODOLOGY}

\subsection{Data set}

i) For the needs of this study after suitable computing processing of raw ERS-2 data, three SAR PRI images (ascending orbit, $C$ band, $\lambda=5,6 \mathrm{~cm}$ and $\mathrm{W}$ polarization system) were obtained:

(a) ERS-2, acquisition date 18/6/1998, orbit 16530, frame 0765, 16 bits, Lat:N38.587, Long.:E22.896, time:22:45

(b) ERS-2, acquisition date 14/1/1999, orbit 19536, frame 0765, 16 bits, Lat.: N 38.587, Long.: E 22.896; time:22:45 and

(c) ERS-2, acquisition date 21/10/1999, orbit 23544, frame 0765,16 bits, Lat:: $N 38.587$, Long.: E 22.896, time:22:45.

ii) A Landsat 7 Enhanced Thematic Mapper (ETM+) image (7 spectral bands) were obtained covering the study area (path 184, row 034), acquisition date: $28^{\text {th }}$ of July 1999 ( $5 \%$ cloud cover).

iii) The wind conditions of the study area during the acquisition day obtained from the National Meteorological Service and are delineated at the following table 1.

iv) East coasts map of Evoikos gulf, scale 1:50.000, from Hydrographical Military Service. 
Table 1. Wind conditions of the study area during the images acquisition period, obtained from Meteorological Station of Lamia.

\begin{tabular}{ccccc}
\hline Date & Hour & Wind direction & Wind Knots & m/sec \\
\hline $18-6-1998$ & $20: 00$ & $110(\mathrm{E})$ & 7 & 3,4 \\
$18-6-1998$ & $23: 00$ & $110(\mathrm{E})$ & 7 & 3,4 \\
$14-1-1999$ & $20: 00$ & $320(\mathrm{NW})$ & 8 & 4,0 \\
$14-1-1999$ & $23: 00$ & $290(\mathrm{~W})$ & 5 & 2,5 \\
$21-10-1999$ & $20: 00$ & $0(\mathrm{~N})$ & 0 & 0 \\
$21-10-1999$ & $23: 00$ & $0(\mathrm{~N})$ & 4 & 1,6 \\
\hline
\end{tabular}

\subsection{Data processing techniques}

The following steps describe the various image processing methods and techniques:

i) Initially, a Digital elevation Model (DEM) of the study area was extracted from the 1:50.000 scale topographic maps published by the Hellenic Army Geographical Service. The contour lines were digitized with an interval of 20 meters in the plain to 40 meters in the highland. Additionally, surface-specific point elevations, including high and low points, were digitized in order to improve the final digital product. A linear interpolation method was applied, based on the Bongefors distance method (ILWIS User's Guide, 2001) aiming to the transformation of the contour data into a DEM, with a spatial resolution of 25 meters. With the intention of verifying its fidelity, the digital elevation model was plotted against to 1:50.000 scale contour map, by interpolating the elevation values and overlapped onto the original topographic map. It showed a very good correspondence of the contour lines.

(ii) Three SAR.PRI radar images were processed, following the creation of a "window" containing the study area, for radiometric correction and enhancement. The main problem associated with SAR data is speckle noise that is caused by random effect of many small individual reflectors within a given pixel (Parcharidis et al.1999). The overall result is an image, with a "salt and pepper" texture, which is distracting to the interpreter. In order to reduce the speckle noise the enhanced Lee adaptive filter was used iteratively, using two continual passes of the filter with different parameters each time (sigma multiplier and window size); this was proved to give the best result among other techniques (Table 2 ).

For the implementation of the filter the specific Coefficient of Variation Value of each image was calculated and presented on table 2, whilst each image was divided into areas of three classes: The first class corresponds to homogeneous areas in which the speckle may be eliminated simply; the second class corresponds to heterogeneous areas in which the speckle is to be reduced while preserving texture; and, the third class corresponds to areas containing isolated point targets, which the filter preserve the already existing value. Following the filtering technique that applied to the images in 16-bit, data were compressed by converting them from 16-bit to 8-bit.

Table 2. The parameters used at the speckle suppression procedure

\begin{tabular}{cccc}
\hline Pass & Sigma Value & Sigma Multiplier & Window size \\
\hline \multirow{2}{*}{1} & $\begin{array}{l}\text { Image } 1: 0.269 \\
\text { Image 2: } 0.268\end{array}$ & 0.5 & $3 \times 3$ \\
& $\begin{array}{l}\text { Image 3: } 0.261 \\
\text { Image 1: } 0.246\end{array}$ & & \\
Image 2: 0.266 & 1.0 & $5 \times 5$ \\
\hline
\end{tabular}

The most important operation was the co-registration of the three images. The accurate spatial registration of the three-day imagery is an essential requirement for effective change detection. The three sub-scenes were geo-referenced to a common map projection, using Transverse Mercator coordinate system (the root mean square error- $r^{2}$-of the 2 nd order polynomial transformation was less than 1 pixel). A Digital Elevation Model (DEM) has been used for orthorectification of the three images.

In several studies on various targets it has been demonstrated that multitemporal ERS data offer more information than single scenes (Kattenborn et al. 1993, Leysen et al. 1993). Thus, a 
Temporal Differentiate Image (TDI) was created using image of October 1999 as Red, image of January 1999 as Green and June 1998 image as Blue. Changes in the backscattering coefficients between the three images provoke a multicolor image that here is represented in a grayscale form (Fig. 3).

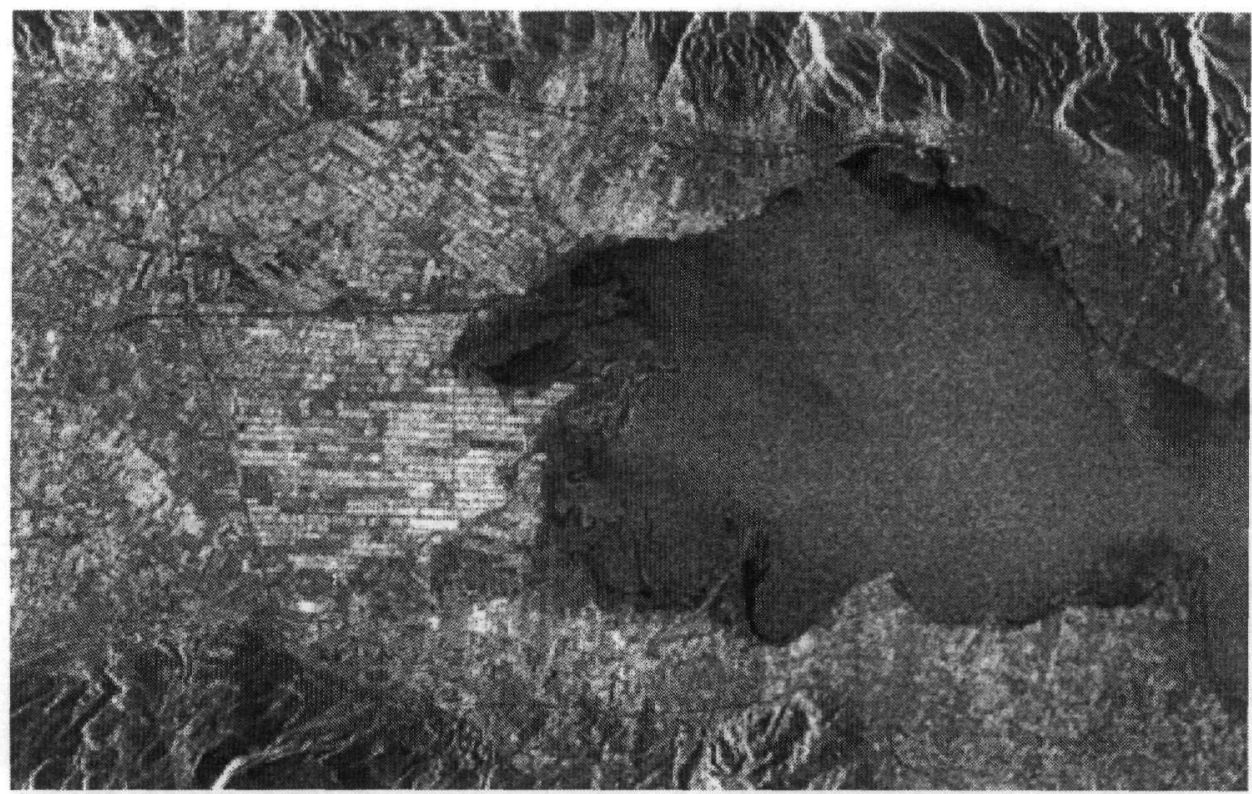

Fig.3. The Temporal Differentiate radar Image (TDI) of the study area. This image reveals mainly the seasonal crop changes appear with white and light gray shades, and coastal shallow waters bathymetry appear with black and dark gray shades at the coastline area.

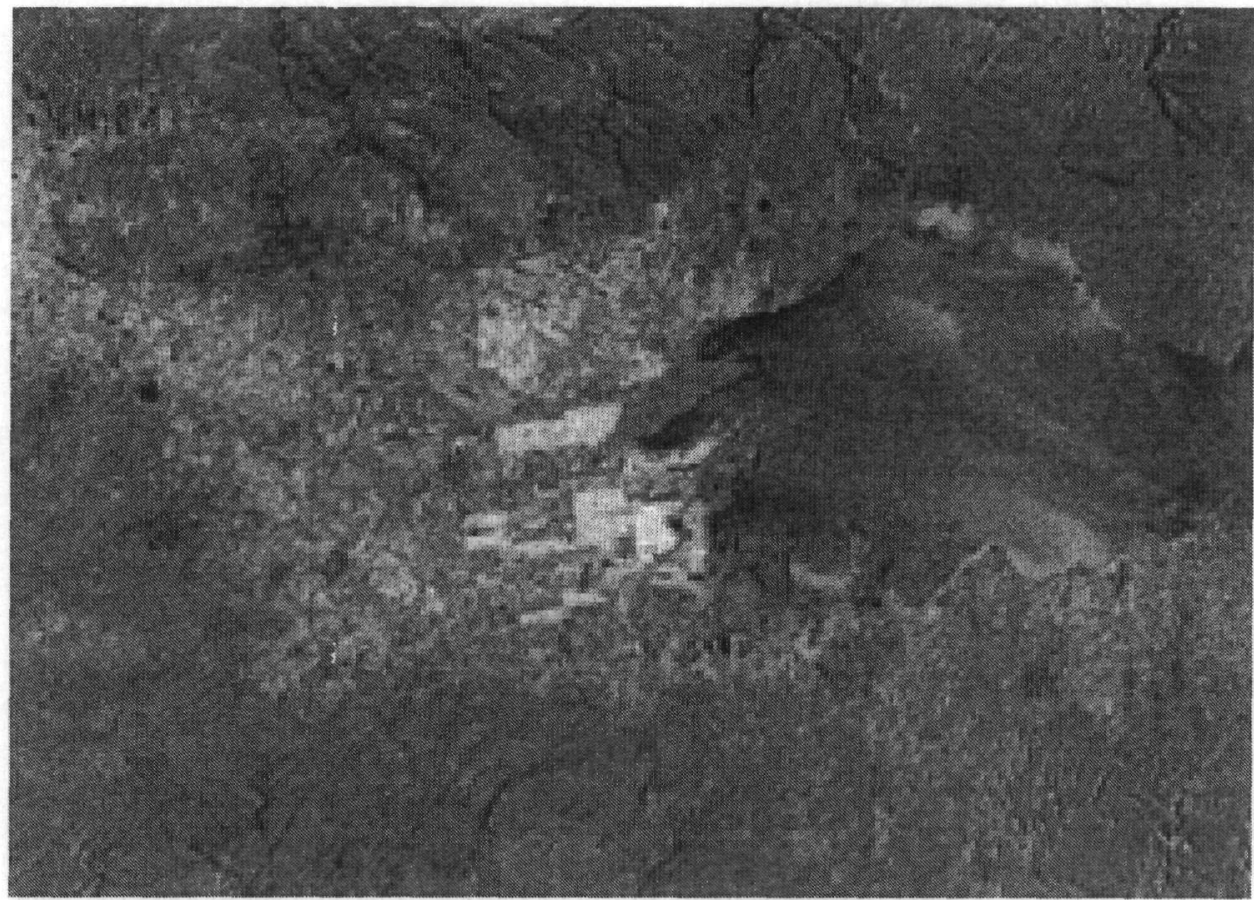

Fig.4. The Principal Component Transform radar Image (TDI) of the study area. 
Furthermore, it was found that various texture features and their combinations in principal component transformations increase the thematic information of SAR images significantly. Consequently, an RGB image of Principal Component Transform (PCT) was created in a grayscale (Fig. 4). The principal components transformation is a statistic technique of many variables, which chooses non-correlated linear compositions (eigenvectors) from a number of variables in such a way, that each output principal component (linear composition) shows the minimum variance. These variables in the multispectral images are related to the spectral response of various surficial characteristics.

Digital image processing of the satellite data was carried out using ERDAS IMAGINE v.8.6 software, while the manipulation of the spatial information and the digitizing of thematic maps were made using ILWIS 3.0. Selected field checks were also took place in order to estimate the accuracy of the interpretation results.

\section{RESULTS AND DISCUSSION}

The purpose of the interpretation of the temporal differentiated radar image was twofold. Firstly, all the changes occurred during the short time period (June 1998-October 1999) were mapped, and secondly, they compared in order to examine the possibility of distinguishing the nature of these changes.

In figure 5a dark gray areas represent areas where the backscattering coefficient is low and remained relative constant through the selected time period. These areas correspond to relatively invariant surface features that are present mainly in the north and south mountainous areas. White and light gray shades at' the coastal plain area are attributed, mainly, to the seasonal changes of crops. Thus, white area correspond to crops with high backscattering in January or both in January and October such as winter crops of wheat and alfalfa or crops, which are cultivated both in winter and summer. The light gray and gray areas correspond to crops with high backscattering in June, or October. During the end of June cotton and maize crops are in the flowering period, the alfalfa is in harvest period and rice is in the initial stage of development. At the end of October, cotton, maize and rice are at the end of harvest period and the backscattering depends on the diversity of each crop.

The black and very dark gray shades on the image correspond to relatively constant very low backscattering surface features such as, the shadowed slopes, big roads and drainage channels and finally to sea water surface condition; the latter characteristic depends on the wind direction which can create a rough or calm water surface (appear white or black respectively) and to water depths differences along the coastline area.

In figure $5 d$ appear the shallow areas at the north part of the gulf close to the small port of Stylida (point 1) which are recorded in the hydrographical map of the area. In the principal component transform image these areas are highlighted and appear more clearly (fig.5b-point 2), while in the Landsat image are indistinguishable (fig.5c). These shallow areas lie to both sides of the port and leave a small bus from which the ships reach the port. 


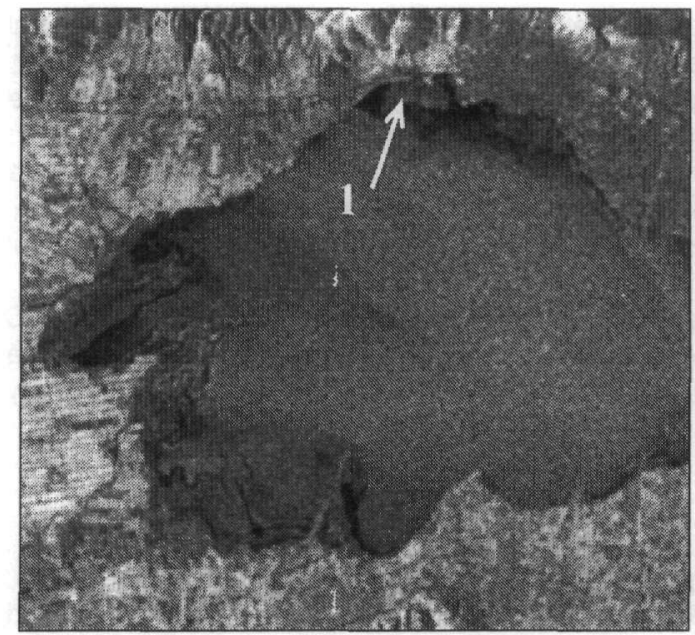

(a)

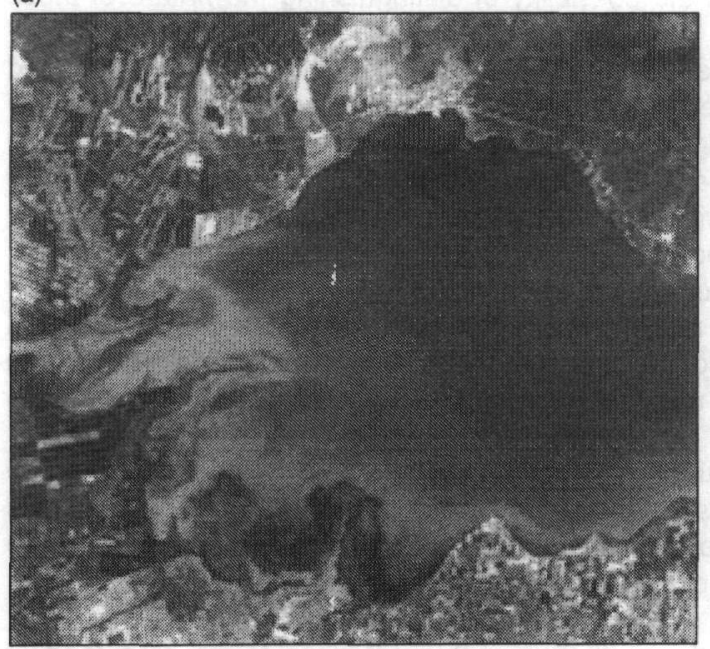

(c)

Fig.5. (a) The Temporal Differentiate radar Image (TDI) of Maliakos gulf (point 1 shows the shallow areas), (b) The Principal Component Transform radar Image (TDI) of the gulf (point 2 shows the shallow areas), (c) The Landsat 7 true color image covers Maliakos gulf, (d) The hydrographical map of Maliakos gulf.

\section{CONCLUSION}

The combination of remote sensing and GIS techniques is a helpful tool for the detection of land use patterns that change over time in response to economic, social and environmental forces. Understanding the nature of changes, either natural or human, is an essential knowledge to facilitate proper planning, management and regulation for coastal areas. The availability of satellite imagery has made them feasible to extract detailed information on landform features over extensive areas of delta lowland areas.

Both methods didn't show any significant seasonal changes of the coastal area. Temporal differentiate radar Image (TDI) reveals specifically the seasonal changes of crops while didn't appear to be useful for any kind of change detection in the mainland.

Principal Component Transform technique highlights more clearly the shallow areas at the north part of Maliakos gulf than the Temporal differentiate image. 


\section{ACKNOWLEDGMENTS}

During preparation of the manuscript the State Scholarships Foundation of Greece supported one of the authors (E. Psomiadis).

\section{REFERENCES}

Ciavola, P., F. Mantovani, U. Simeoni and Tessari, U., 1999: Relation between river dynamics and coastal changes in Albania: an assessment integrating satellite imagery with historical data. . Int. J. Remote Sensing, Vol. 20, No 3, 561-584.

Constanza, R., R. d'agre, R. de Groot, S. Farber, M. Grasso, B. Hannon, K. Limburg, S. Naeem, R.V. O'Neill, J. Paruelo, R.G. Raskin, P. Sutton and Van den Belt, M., 1997. The value of the world's ecosystem services and natural capital. Nature, Vol.387, 253-260.

Ferrière, J., 1977. Faits nouveaux concernant la zone isopique maliaque (Grèce continental orientale).Proceed. VI Colloquium Geology of the Aegean region, 1977, I: 197-210.

Gartzos, E. and Stamatis, G., 1996. Genesis of the thermal springs of the Sperchios graben, Greece. N.Jb.Geol.Paläont.Mh., 1996 (2): 91-115; Stuttgart.

ILWIS 3.0 FOR WINDOWS User's Guide, 2001. ILWIS Dept. ITC.

Kattenborn, G., Nezry, E., De Grandi, G., and Sieber, A.J., 1993. High resolution detection and monitoring of changes using ERS-1 time series. Proceedings of 2nd ERS-1 Symposium, Hamburg, Germany, 11-14 October 1993 (ESA, ESTEC: The Netherlands), pp. 635-642.

Kuntz, S. and Siegert, F. 1999. Monitoring of deforestation and land use in Indonesia with multitemporal ERS data. Int. J. Remote Sensing, Vol. 20, No. 14, 2835-2853.

Levsen, M., Conway, J.A., and Sieber, A., 1993. Evaluating multi-temporal ERS-1 data for tropical forest mapping: regional mapping and change detection applications. Proceedings of 2nd ERS-1 Symposium, Hamburg, Germany, 11-14 October 1993 (ESA, ESTEC: The Netherlands).

Maroukian, H. \& E. Lagios (1987): Neotectonic movements in the Sperchios River basin, Central Greece. Zeitschrift für Geomorphologie, Suppl.Band, 63, 133-140.

Parcharidis, Is., Pavlopoulos, A., Serelis, K., Tsintzuras, S. 1999. Man-made impact monitoring in Messolongi lagoon system using multitemporal ERS.SAR data. Proceedings of $6^{\text {th }}$ International Conference on Environmental Science and Technology, Vol. B, 416-423.

Pirazzoli, P.A., S.C. Stiros, M. Arnold, J. Laborel \& F. Laborel-Deguen (1999): Late Holocene coeseismic vertical displacements and tsunami deposits near Kynos, gulf of Euboea, central Greece. Phys. Chem. Earth (A), Vol.24, No 4, 361-367.

Poulos, S., S. Leontaris, \& M.B. Collins (1997): Sedimentological and clay mineralogical investigations in Maliakos Gulf, eastern Greece. Boll. Geof. Teor.Appl, 38, 3-4, 267-279.

Shaghude, Y.W., K.O. Wannäs \& B. Lundén, (2003): Assessment of shoreline changes in the western side of Zanzibar channel using satellite remote sensing. Int. J. Remote Sensing, Vol. 24, No 23, 4953-4967.

Stahl, W., H. Aust, A. Dounas \& A. Kakavas (1975): Groundwater investigations, Sperchios basin/central Greece 1970-74. Internal. Report, IX: Stable isotope composition of different ground and surface waters from the Sperchios valley, p.40, Athens, I.G.M.E., (Unpubl).

Rao, B.R.M., Dwivedi, R.S., Kushwaha, S.P.S., Bhattacharya, S.N., Anand, J.B.., and Dasgupta, S., 1999. Monitoring the spatial extent of coastal wetlands using ERS-1. Int. J. Remote Sensing, Vol. 20, No. 13, 2509-2517.

Therianos, A.D. (1974): The geographical distribution of river water supply in Greece, Bull. Geol. Soc. Greece, 11, 28-58, (in Greek).

White, K. \& H.M. El Asmar (1999): Monitoring changing position of coastlines using Thematic Mapper imagery, an example from the Nile Delta. Geomorphology, Vol.29, 93-105.

Yang, X., Damen, M.C.J., Van Zuidam, R.A. 1999. Use of Thematic Mapper imagery with a geographic information system for geomorphologic mapping in a large deltaic lowland environment. Int. J. Remote Sensing, Vol. 20, No. 4, 659-681.

Zamani, A., Maroukian, H., 1979. A morphological study of an old delta of the Sperchios River. VI Colloquium on the Geology of the Aegean Region, Proceedings, Athens, 1977, 1, 417-423.

Zamani, A., Maroukian, H., 1980. Deltaic sedimentation of the Sperchios River in historical times. Annales Geologiques du Pays Helleniques, 30, 430-440. 